\title{
Energy under-reporting in Swedish and Irish dietary surveys: implications for food-based dietary guidelines
}

\author{
Wulf Becker ${ }^{1}$, Sharon Foley ${ }^{2}$, Emer Shelley ${ }^{3}$ and Michael Gibney ${ }^{2 *}$ \\ ${ }^{1}$ National Food Administration, Box 622, SE-751 26 Uppsala, Sweden \\ ${ }^{2}$ Department of Clinical Medicine, Trinity College, Dublin 2, Ireland; Eastern Health Board, Dr Stephen's Hospital, \\ Dublin, Ireland \\ ${ }^{3}$ Eastern Health Board, St. Steven's Hospital, Dublin 8, Ireland
}

\begin{abstract}
An analysis of dietary survey data from Sweden and Ireland revealed that with a declining ratio of energy intake to estimated basal metabolic rate (EI : BMR), \%energy from fat, saturated fat and carbohydrate fell while that of protein increased. However, where the definition of underreporting is less strict, as in the Irish database (EI:BMR) $<1.27)$, the quantitative effect on macronutrient balance, while statistically significant, is not of such magnitude as to be of nutritional significance. However, with respect to foods, under-reporting was found to be of considerable significance in using such data to formulate food-based dietary guidelines. The Swedish data show that under-reporting of foods is associated with a decreasing percentage of consumers, decreasing intake per eating occasion and decreasing frequency of eating. The development of food-based dietary guidelines will involve comparisons of patterns of food intake among people with contrasting high or low intakes of target nutrients. The Swedish data compared food intakes for those with low or high intakes of saturated fatty acids (SFA) among under-reporters and acceptable reporters of energy intake. Whereas absolute values were always lower with the lower EI : BMR group $(<1 \cdot 1)$ compared to the higher EI : BMR group $(>1.35)$ the ratio of intakes for the low vs. high SFA groups were broadly significant at either EI : BMR ratio. This paper highlights the difficulties that under-reporting will pose for food-based dietary guidelines.
\end{abstract}

Dietary under-reporting: Food-based dietary guidelines: Sweden: Ireland

The majority of studies of diet in relation to health are based on the assumption that current methods of dietary assessment are capable of providing valid measures of habitual dietary intakes (Black et al. 1993). A fundamental principle of energy physiology is that if body weight and body composition are stable, then energy intake must equal energy output. However, for many surveys, reported energy intakes are consistently lower than estimates of energy intake commensurate with stable body weight (Livingstone et al. 1990). The advent of more sophisticated techniques to measure expenditure, such as doubly labelled water, has allowed reported energy intakes to be validated, externally and internally (Schoeller, 1988). In the absence of an external validation, an estimate of basal metabolic rate (BMR) based on age, sex and body weight can be used as an internal validation of reported energy intake. Work using both methods of validation has demonstrated conclusively the widespread problem of under-reporting of energy intake and has provided reference values for detecting under-reporting (Goldberg et al. 1991; Black et al. 1996).

Obese or weight-conscious subjects in particular have been found to be over-represented among under-reporters (Bandini et al. 1990; Prentice \& Jebb, 1995; Black et al. 1996). Under-reporting has also been noted in pregnant women (Goldberg et al. 1993) and in children and adolescents (Livingstone et al. 1992). Under-reporting has been shown to be present across a range of energy intakes (Lissner et al. 1989; Livingstone et al. 1990) and has been observed with all methods of measuring energy intake.

Under-reporting may involve the failure to report eating occasions or to report eating occasions correctly but underreport portion size. To date, there has not been any systematic examination of patterns of food intake in subjects with acceptable or unacceptable reported energy intakes. This paper sets out to provide a preliminary analysis of such, which may be critically important to the derivation of food-based dietary guidelines. 


\section{Methods}

During 1989, a combined household and dietary survey (the 'HULK survey') of the Swedish population was carried out by Statistics Sweden in collaboration with the National Food Agency. Each household was asked to record all the foods it purchased over a 4-week period. For food eaten outside the home, only expenditures were recorded. Food intake for one household member was measured using a simplified $7 \mathrm{~d}$ record with precoded alternatives (expressed household measures) for food consumed. Using a portionguide with photographs, sizes of cooked food portions eaten at main meals and fat spreads used on sandwiches could be estimated. Approximately 2000 subjects, aged 1-74 years old, completed the study with a participation rate of $70 \%$.

The Irish food intake database used in the present study was that of the Kilkenny Health Project, full details of which have been described by Shelley et al. (1995). The mean age for men was 47.2 years $(n=1120)$ and for females it was 48.1 years $(\mathrm{n}=1092)$. A food-frequency questionnaire was developed based on that used in the Caerphilly-Speedwell Prospective Heart Study (Yarnell et al. 1983). The questionnaire recorded frequency of consumption of 78 foods representing 10 broad food categories.

For the Swedish study, subjects were classified into three categories of the ratio of reported energy intake to estimated BMR (EI : BMR): $<1 \cdot 10,1 \cdot 10-1 \cdot 34$ and $>1 \cdot 35$. For the Irish study, subjects were classified as those with acceptable energy intakes (EI : BMR >1.27) or those under-reporting energy intakes (EI: BMR < 1.27). For the purposes of the present paper, it is not important to focus on exactly which cut-off points are used to determine under-reporting. Rather, it is essential to examine whether reasonable cut-off points of EI : BMR influence estimates of both nutrient and food intake.

\section{Results and discussion}

Table 1 shows that variation in the ratio of energy intake to estimated basal metabolic rate (EI : BMR) is associated with variation in \%energy from various macronutrients. The classification of Swedish subjects allows for an examination of more extreme under-reporting than for Irish subjects and it may that this explains why the quantitative effect of under-reporting in Sweden is greater than it is in Ireland. By and large, increasing levels of under-reporting in both countries tend to be associated with lower \%energy from total fat, saturated fat and carbohydrate with a higher \%energy from protein. The less stringent divisions used for the analysis of the Irish data would suggest that whereas under-reporting is associated with altered \%energy from macronutrients, the quantitative differences are not so great as to lead to mistaken conclusions with regard to macronutrient balance. The Swedish data would suggest that the more severe the cut-off for under-reporting, the greater is the effect on macronutrient balance.

Table 2 presents data on aspects of the intakes of vegetables, fruit and spreads in Swedish men and women at varying EI:BMR ratios. As under-reporting increases, the reported intakes of all these foods decrease, the biggest effect being seen for spreads. In all cases, not only is intake as $\mathrm{g} / \mathrm{d}$ reduced, but the reported frequency of consumption within a day is also reduced. Equally, the proportion of subjects reporting eating these foods declines with increasing level of under-reporting. These data show that lower reported food intake among under-reporters is characterized both by their declaration not to be a consumer and by those who consume reporting a lower overall intake. Moreover, if intake/d is divided by occasions/d to give an indication of intake per occasion of eating, it is evident that for some foods there is also under-reporting per eating occasion. Thus under-reporting may be characterized by denial of consumption, by under-reporting eating occasions, and by under-reporting the quantity eaten per eating occasion.

The data on food intake pattern for subjects with acceptable or unacceptable reported energy intakes (EI : BMR of $\geq 1.27$ and $<1.27$ respectively) for Irish subjects focuses on high or low reported frequency of consumption of foods (Table 3). Thus, among bread consumers, in those consuming low levels $(0-2$ slices per day) there is gross overrepresentation of under-reporters. In contrast, among those with a high intake of bread ( $>6$ slices per day) there is gross under-representation of under-reporters. For each food the same is true: there is gross under-representation of underreporters among butter consumers, frequent consumers of fried foods, habitual milk drinkers, sugar and confectionery consumers and sugar consumers to mention just some foods. For some foods, reported low intakes occur equally for

Table 1. Patterns of nutrient intake in Swedish and Irish men classified according to varying ratios of energy intake to estimated basal metabolic rate (EI : BMR)

\begin{tabular}{|c|c|c|c|c|c|}
\hline & \multicolumn{3}{|c|}{$\begin{array}{l}\text { Sweden } \\
\text { El:BMR }\end{array}$} & \multicolumn{2}{|c|}{$\begin{array}{l}\text { Ireland } \\
\text { EI:BMR }\end{array}$} \\
\hline & $<1 \cdot 10$ & $1 \cdot 10-1 \cdot 34$ & $>1.35$ & $<1.27$ & $\geq 1.27$ \\
\hline$\%$ of subjects & 26 & 27 & 46 & 53 & 47 \\
\hline Energy (MJ/d) & $7 \cdot 0$ & $9 \cdot 2$ & $12 \cdot 0$ & 7.9 & 11.7 \\
\hline \multicolumn{6}{|l|}{ \%energy from: } \\
\hline Total fat & 34.8 & 35.8 & $37 \cdot 3^{* * *}$ & 39.4 & $40 \cdot 3^{\star \star \star}$ \\
\hline Saturated fat & $15 \cdot 4$ & $15 \cdot 9$ & $17 \cdot 0^{\star *}$ & $17 \cdot 0$ & $18 \cdot 0^{\star \star \star}$ \\
\hline Polyunsaturated fat & 4.9 & $5 \cdot 3$ & $5 \cdot 4^{* \star *}$ & 5.4 & $5 \cdot 0$ \\
\hline Protein & $15 \cdot 8$ & $15 \cdot 0$ & $14 \cdot 4^{\star \star \star}$ & $16 \cdot 5$ & $14 \cdot 6^{\star * *}$ \\
\hline Carbohydrate & $45 \cdot 8$ & $46 \cdot 0$ & $46 \cdot 2$ & $4 \cdot 1$ & $45 \cdot 2^{\star \star \star}$ \\
\hline
\end{tabular}

Significant difference across groups within a country: ${ }^{* \star} P<0.01$ : $^{\star \star \star} P<0.001$ 
Table 2. Patterns of food intake in Swedish subjects classified according to varying ratios of energy intake to estimated basal metabolic rate (EI:BMR)

\begin{tabular}{|c|c|c|c|c|c|c|}
\hline & \multicolumn{3}{|c|}{$\begin{array}{c}\text { Men } \\
\text { El : BMR }\end{array}$} & \multicolumn{3}{|c|}{$\begin{array}{l}\text { Women } \\
\text { El:BMR }\end{array}$} \\
\hline & $<1.0$ & $1 \cdot 0-1 \cdot 34$ & $>1.35$ & $<1.0$ & $1 \cdot 0-1 \cdot 34$ & $>1.35$ \\
\hline \multicolumn{7}{|l|}{ Intake $(\mathrm{g} / \mathrm{d})$} \\
\hline Vegetables & 61 & 70 & 83 & 75 & 74 & 94 \\
\hline Fruit & 86 & 93 & 120 & 111 & 108 & 151 \\
\hline Spreads & 15 & 25 & 42 & 10 & 14 & 20 \\
\hline \multicolumn{7}{|l|}{ Occasions/d } \\
\hline Vegetables & $1 \cdot 12$ & 1.31 & 1.47 & 1.55 & 1.54 & 1.90 \\
\hline Fruit & 0.75 & 0.81 & 1.04 & 1.02 & 1.09 & 1.45 \\
\hline Spreads & 1.46 & 1.88 & $2 \cdot 27$ & 1.37 & 1.72 & 2.02 \\
\hline \multicolumn{7}{|l|}{$\%$ consumers } \\
\hline Vegetables & 94 & 98 & 98 & 98 & 99 & 100 \\
\hline Fruit & 79 & 87 & 93 & 89 & 94 & 98 \\
\hline Spreads & 91 & 96 & 96 & 92 & 95 & 98 \\
\hline \multicolumn{7}{|c|}{ Intake (g/eating occasion) } \\
\hline Vegetables & 54 & 72 & 82 & 48 & 48 & 79 \\
\hline Fruit & 114 & 115 & 115 & 129 & 99 & 104 \\
\hline Spreads & 10 & 13 & 19 & 7 & 8 & 10 \\
\hline
\end{tabular}

acceptable and under-reporters, e.g. vegetables (men), fruit (men and women), boiled potatoes (women), and sugar (women). However, for higher intakes there is usually a disproportionately low representation of under-reporters. Effectively speaking, the under-reporters tend to underreport foods rich in protein, fat and carbohydrate and do so such that the marked differences in food under-reporting, whilst obviously reflected in energy under-reporting, do not grossly distort the balance of macronutrient intake as seen in Table 1. Taken together, the data in Tables 2 and 3 show that defining patterns of food intake in the derivation of foodbased dietary guidelines will be seriously hampered by the phenomenon of under-reporting of food intake.

In an attempt to explore whether there might be ways of examining food intake data for the derivation of food-based dietary guidelines that might overcome the issue of underreporting, the Swedish data was re-examined for high and low EI:BMR and within each of these categories for high and low \%energy from saturated fatty acids (SFA). The results are given in Table 4 . The reported intakes of almost all foods were lower among under-reporters compared to those with acceptable energy intakes, irrespective of whether the groups were high or low with respect to $\%$ energy from SFA. However, the ratio of food intakes of those with high to those with low SFA intakes, by and large, tended to agree. The exceptions were potatoes, juice and meat. Thus, if absolute food intakes are ignored and ratios of food intakes are examined (high:low SFA), there may be some possibility of identifying food patterns indicative of contrasting SFA intake. Foods that tend positively to discriminate toward a high-SFA diet are spreads, cheese and sausages, while those that negatively discriminate toward a high-SFA diet are vegetables, fruit and juice. However, whilst this approach with food-intake ratios may be of some help in developing food-based dietary guidelines, such guidelines, if they are to be meaningful to consumers, must have some quantitative direction. For example, irrespective of energy reporting, high intakes of cheese are inter alia associated with high-SFA ( $>18 \%$ energy) diets (40-50 g/d), but people with reasonably low intakes of SFA $(<13 \%$ energy) happily eat cheese at lower levels at around $25 \mathrm{~g} / \mathrm{d}$. Consumers

Table 3. Ratio of acceptable reporters $(E I: B M R \geq 1.27)$ to underreporters $(E I: B M R<1.27)$ in Irish adult males and females for low and high frequency of consumption of selected foods

\begin{tabular}{|c|c|c|c|}
\hline \multirow[b]{2}{*}{ Food } & \multirow{2}{*}{$\begin{array}{l}\text { Frequency } \\
\text { type }\end{array}$} & \multicolumn{2}{|c|}{$\begin{array}{l}\text { Ratio of acceptable } \\
\text { reporters to } \\
\text { under-reporters }\end{array}$} \\
\hline & & Males & Females \\
\hline Bread & $\begin{array}{l}0-2 \text { slices } / d \\
>6 \text { slices } / d\end{array}$ & $\begin{array}{l}0.27 \\
3.76\end{array}$ & $\begin{array}{l}0.36 \\
6 \cdot 14\end{array}$ \\
\hline Cereals & $\begin{array}{l}0-3 \text { servings/wk } \\
\geq 7 \text { servings/wk }\end{array}$ & $\begin{array}{l}1.00 \\
1.27\end{array}$ & $\begin{array}{l}1.23 \\
2.03\end{array}$ \\
\hline Fruit & $\begin{array}{l}\text { None } \\
>14 \text { pieces/wk }\end{array}$ & $\begin{array}{l}1.04 \\
0.79\end{array}$ & $\begin{array}{l}1.12 \\
1.63\end{array}$ \\
\hline Vegetables & $\begin{array}{l}0-2 \text { servings/d } \\
\geq 3 \text { servings } / d\end{array}$ & $\begin{array}{l}1.04 \\
1.56\end{array}$ & $\begin{array}{l}1.27 \\
1.94\end{array}$ \\
\hline Boiled potatoes & $\begin{array}{l}0-4 \text { times/wk } \\
7 \text { times/wk }\end{array}$ & $\begin{array}{l}0.85 \\
1.43\end{array}$ & $\begin{array}{l}1.00 \\
1.70\end{array}$ \\
\hline Chips & Non-consumer & 0.85 & 0.92 \\
\hline Spread & $\begin{array}{l}\text { Butter } \\
\text { Low fat }\end{array}$ & $\begin{array}{l}1.56 \\
0.52\end{array}$ & $\begin{array}{l}1.94 \\
0.81\end{array}$ \\
\hline Fried foods & $\begin{array}{l}\text { None } \\
>6 \text { times/wk }\end{array}$ & $\begin{array}{l}0.75 \\
2.44\end{array}$ & $\begin{array}{l}0.66 \\
4.55\end{array}$ \\
\hline Milk & $\begin{array}{l}<0.5 \mathrm{pint} / \mathrm{d} \\
>1.0 \mathrm{pint} / \mathrm{d}\end{array}$ & $\begin{array}{l}0.67 \\
2.86\end{array}$ & $\begin{array}{l}1.17 \\
8.09\end{array}$ \\
\hline Eggs & $\begin{array}{l}0-2 / w k \\
\geq 5 / w k\end{array}$ & $\begin{array}{l}0.82 \\
1.85\end{array}$ & $\begin{array}{l}1.22 \\
2.00\end{array}$ \\
\hline Red meat & $>6$ servings/wk & 1.94 & $3 \cdot 16$ \\
\hline Sweets/confectionery & $>7$ times $/ w k$ & $2 \cdot 70$ & $1 \cdot 76$ \\
\hline Sugar & $\begin{array}{l}\text { None } \\
>10 \text { spoons/d }\end{array}$ & $\begin{array}{l}0.64 \\
3.54\end{array}$ & $\begin{array}{l}0.96 \\
5.25\end{array}$ \\
\hline
\end{tabular}


Table 4. Patterns of food intake in Swedish women classified according to both ratio of energy intake to estimated basal metabolic rate (EI:BMR) and to \%energy from saturated fatty acids (SFA)

\begin{tabular}{|c|c|c|c|c|c|c|}
\hline & \multicolumn{3}{|c|}{$\mathrm{El}: \mathrm{BMR}<1.1$} & \multicolumn{3}{|c|}{$\mathrm{El}: \mathrm{BMR}>1.35$} \\
\hline & \multicolumn{2}{|c|}{ SFA \%energy } & \multirow[b]{2}{*}{ Ratio } & \multicolumn{2}{|c|}{ SFA \%energy } & \multirow[b]{2}{*}{ Ratio } \\
\hline & $<13$ & $>18$ & & $<13$ & $>18$ & \\
\hline Energy (MJ/d) & $5 \cdot 1$ & $5 \cdot 7$ & & 8.9 & 9.5 & \\
\hline \multicolumn{7}{|l|}{ Intake $(\mathrm{g} / \mathrm{d})$} \\
\hline Spread & 8 & 15 & 1.9 & 13 & 30 & $2 \cdot 4$ \\
\hline Cheese & 23 & 39 & $1 \cdot 7$ & 28 & 49 & 1.8 \\
\hline Milk & 279 & 307 & $1 \cdot 1$ & 407 & 430 & 1.1 \\
\hline Bread & 62 & 62 & 1.0 & 90 & 93 & 1.0 \\
\hline Potatoes & 75 & 89 & 1.2 & 161 & 121 & 0.8 \\
\hline Vegetables & 121 & 65 & 0.5 & 139 & 85 & 0.6 \\
\hline Fruit & 197 & 53 & 0.3 & 217 & 115 & 0.5 \\
\hline Juice & 39 & 26 & 0.7 & 128 & 49 & 0.4 \\
\hline Meat & 72 & 60 & 0.8 & 74 & 80 & 1.1 \\
\hline Sausages & 10 & 16 & 1.6 & 12 & 23 & 1.9 \\
\hline Buns, cakes & 19 & 24 & 1.3 & 48 & 59 & 1.2 \\
\hline
\end{tabular}

Table 5. Energy adjusted intakes and ratios of intakes of foods ( $\mathrm{g} / 10 \mathrm{MJ}$ per day) in subjects with low and high \%energy from saturated fatty acids (SFA) classified into low and high ratios of energy intake to estimated basal metabolic rate (EI :BMR)

\begin{tabular}{|c|c|c|c|c|c|c|}
\hline & \multicolumn{2}{|c|}{$<13 \%$ energy } & \multirow{2}{*}{$\begin{array}{l}\text { Ratio of } \\
\text { intake }\end{array}$} & \multicolumn{2}{|c|}{$>18 \%$ energy } & \multirow{2}{*}{$\begin{array}{c}\text { Ratio of } \\
\text { intake }\end{array}$} \\
\hline & $<1.1$ & $>1.35$ & & $<1.1$ & $>1.35$ & \\
\hline Spread & 16 & 15 & $1 \cdot 1$ & 26 & 32 & 0.8 \\
\hline Cheese & 45 & 31 & 1.5 & 68 & 52 & 1.3 \\
\hline Milk & 547 & 457 & 1.2 & 538 & 453 & 1.2 \\
\hline Bread & 121 & 101 & 1.2 & 109 & 98 & 1.1 \\
\hline Potatoes & 147 & 181 & 0.8 & 156 & 127 & 1.2 \\
\hline Vegetables & 237 & 156 & 1.5 & 114 & 89 & 1.3 \\
\hline Fruit & 386 & 243 & 1.6 & 93 & 121 & 0.8 \\
\hline Juice & 76 & 144 & 0.5 & 46 & 52 & 0.9 \\
\hline Meat & 141 & 83 & 1.7 & 105 & 84 & 1.3 \\
\hline Sausages & 20 & 13 & 1.5 & 28 & 24 & 1.2 \\
\hline Buns, cakes & 37 & 54 & 0.7 & 42 & 62 & $0 . \overline{7}$ \\
\hline
\end{tabular}

need guidelines as to what are reasonable daily intakes of specific foods if food-based dietary guidelines are to be useful. In the case of spreads, the picture is much less clear cut than for cheese and it would be difficult to advise on a figure. The intake of spreads among acceptable reporters is $13 \mathrm{~g} / \mathrm{d}$ for those with a low-SFA diet, and just $15 \mathrm{~g} / \mathrm{d}$ for under-reporters with a high-SFA diet. In an attempt to see if correcting food intake for energy intake would be useful, the Swedish data were adjusted to g/10 MJ per day. The data are shown in Table 5. The ratios of intakes of low versus high EI : BMR groups reveals that energy adjustment does not give a consistent correction to under-reporting. In fifteen out of twenty-two instances, adjustment for energy intake leads to higher estimates of intakes among under-reporters, irrespective of SFA \%energy. However, it might be possible to begin to develop quantitative food-based guidelines to consumers following correction for energy intake if portion sizes are used and not intakes as g/10 MJ per day.

It was not the intention of this paper to identify all of the problems of under-reporting as it relates to food-based dietary guidelines; neither was it intended to offer solutions.
The objective was to highlight the problem, reflect on it and in so doing reveal the need for urgent research into this area.

\section{References}

Bandini LG, Schoeller DA, Cyr HN, Dietz WH (1990) Validity of reported energy intake in obese and nonobese adults. American Journal of Clinical Nutrition 52, 421-425.

Black AE, Prentice AM, Goldberg GR, Jebb SA, Bingham SA \& Livingstone MBE (1993) Measurements of total energy expenditure provide insights into the validity of dietary measurements of energy intake. Journal of the American Dietetic Association 93, 572-579.

Black AE, Coward WAZ, Cole TJ \& Prentice AM (1996) Human energy expenditure in affluent societies: an analysis of 574 doubly-labelled water measurements. European Journal of Clinical Nutrition 50, 72-92.

Goldberg GR, Black AE, Jebb SA, Cole TJ, Murgatroyd WA, Coward WA \& Prentice AM (1991) Critical evaluation of energy intake data using fundamental principles of energy physiology: 1. Derivation of cut-off limits to identify underrecording. European Journal of Clinical Nutrition 45, 569-581. 
Goldberg GR, Prentice AM, Coward WA, Davies HL, Murgatroyd PR, Wensing C, Black AE, Harding M \& Sawyer M (1993) Longitudinal assessment of energy expenditure in pregnancy by the doubly labelled water method. Americal Journal of Clinical Nutrition 57, 494-505.

Lissner L, Habicht JP, Strupp BJ, Levitsky DA, Haas JD \& Roe DA (1989) Body composition and energy intake: do overweight women overeat and under-report? Americal Journal of Clinical Nutrition 49, 320-325.

Livingstone MBE, Prentice AM, Strain JJ, Coward WA, Black AE, Barker ME, McKenna PG \& Whitehead RG (1990) Accuracy of weighed dietary records in studies of diet and health. British Medical Journal 300, 708-712.

Livingstone MBE, Prentice AM, Coward WA, Strain JJ, Black AE, Davies PSW, Stewart CM, McKenna PG \& Whitehead RG (1992) Validation of estimates of energy intake by weighed dietary record and diet history in children and adolescents. American Journal of Clinical Nutrition 56, 29-35.

Prentice AM \& Jebb SA (1995) Obesity in Britain: Gluttony or Sloth? British Medical Journal 311, 437-439.

Schoeller DA (1988) Measurement of energy expenditure in freeliving humans by using double labeled water. Journal of Nutrition 118, 1278-1289.

Shelley E, Daly L, Collins C, Christie M, Conroy R, Gibney M, Hickey N, Kelleher C, Kilcoyne D, Lee P, Mulcahy R, O’Dwyer T, Radic A \& Graham I (1995) Cardiovascular risk factor changes in the Kilkenny Health Project, a Community Health Promotion Programme. European Heart Journal 16, 752-760.

Yarnell JWG, Fehily AM, Milbank JE, Sweetman PM \& Walker CL (1983) A short dietary questionnaire for use in an epidemiological survey: comparison with weighted dietary records. Human Nutrition: Applied Nutrition 37A, 103-112. 